\title{
Clinical efficacy and safety of olmesartan/ hydrochlorothiazide combination therapy in patients with essential hypertension
}

\author{
Luis M Ruilope \\ Unidad de Hipertensión, Hospital \\ 12 de Octubre, Madrid, Spain
}

Correspondence: Luis Miguel Ruilope Unidad de Hipertension, Hospital 12 de Octubre, 2804I Madrid, Spain Tel +34 913908284

Fax +34915765644

Email ruilope@ad-hocbox.com

\begin{abstract}
Hypertension is a major risk factor for cardiovascular disease that contributes to the premature death of millions of people each year, and identification and treatment of hypertension continues to be a challenge. Guidelines recommend that many patients will require two or more antihypertensive agents from different classes. Combining an angiotensin II receptor blocker (ARB) with hydrochlorothiazide (HCTZ) has been shown in clinical studies to increase the antihypertensive efficacy of both agents compared with either agent alone. This review covers several clinical trials and aims to examine several aspects of the efficacy of the combination of olmesartan and HCTZ, including dose-responsiveness, long-term efficacy, goal rate achievement, and efficacy in patients with moderate to severe hypertension. The results presented here demonstrate that olmesartan is effective when added to HCTZ monotherapy or when HCTZ is added to olmesartan monotherapy, both over the short and long term. Moderate to severe hypertension responds well to olmesartan/HCTZ combination therapy, and the great majority of patients are able to achieve recommended blood pressure targets. Thus olmesartan/HCTZ is a well-tolerated option for patients who fail to respond to monotherapy and as initial therapy in those who require large reductions in diastolic blood pressure or systolic blood pressure to achieve goal blood pressure.
\end{abstract}

Keywords: hypertension, olmesartan medoxomil; hydrochlorothiazide, angiotensin II receptor blocker, thiazide diuretic

\section{Introduction}

Hypertension is a major risk factor for cardiovascular disease that contributes to the premature death of millions of people each year (Chobanian et al 2003). The relationship between blood pressure and morbidity and mortality is linear (Lewington et al 2002; Chobanian et al 2003); thus, the greater the reduction in blood pressure the greater the reduction in risk (Hansson et al 1998). Well defined targets for blood pressure have been established in treatment guidelines (Chobanian et al 2003; Whitworth 2003; Mancia et al 2007), and state that blood pressure targets should be $<140 / 90 \mathrm{mmHg}$, or $<130 / 80 \mathrm{mmHg}$ for patients with diabetes or renal disease.

While the percentage of patients meeting these targets has increased in recent years (Chobanian et al 2003), identification and treatment of hypertension continues to be a challenge. The vast majority of patients will require two or more antihypertensive agents from different classes (Hansson et al 1998; Cushman et al 2002; Dahlof et al 2002; Chobanian et al 2003), and in attempting to achieve the lower blood pressure target, or where a patient has more severe hypertension, three or more antihypertensive agents may be required (Chobanian et al 2003). Guidelines recommend initiation of combination therapy when diastolic blood pressure (DBP) values are $\geq 10 \mathrm{mmHg}$ above the DBP target or if SBP is $\geq 20 \mathrm{mmHg}$ above the systolic blood pressure (SBP) target (Chobanian et al 2003; 
Whitworth 2003) and thus effective and well-tolerated combination therapies are required to manage patients who fail to respond to antihypertensive monotherapy.

For several years, thiazide diuretics such as hydrochlorothiazide (HCTZ) have been first-line treatment for hypertension (Psaty et al 1997; Chobanian et al 2003; Psaty et al 2003), and several fixed-dose combinations with other classes of antihypertensive agents such as beta-blockers, angiotensinconverting enzyme (ACE) inhibitors, and angiotensin II receptor blockers (ARBs) are now available. While the mechanism of action for the antihypertensive effect of thiazides is not fully elucidated, it is known that they cause indirect activation of the renin-angiotensin system (RAS), providing a rationale for combining HCTZ with ACE inhibitors and ARBs. Thiazides lower blood pressure in patients with volume-sensitive hypertension, by induction of volume contraction. Volume contraction is a stimulus for renin release and elevation of background RAS activity. A high level of RAS activity is necessary for optimal blockade by an ACE inhibitor or an ARB. Combining an ARB with HCTZ has been shown in clinical studies to increase the antihypertensive efficacy of both agents compared with either agent alone (Benz et al 1998; Kochar et al 1999; Dahlof et al 2002). In contrast, while the antihypertensive effect of both drugs together is additive, a meta-analysis of combination therapy demonstrates that the prevalence of adverse events was less than would be expected with additive effects (Law et al 2003).

Olmesartan is the most recently introduced ARB, which has been shown to produce greater reductions in blood pressure than a range of antihypertensive agents including other ARBs (Ball et al 2001; Puchler et al 2001; Stumpe and Ludwig 2002; Brunner and Laeis 2003). Olmesartan is also available as a fixed-dose combination with HCTZ. In this review, we examine the efficacy and safety of olmesartan plus HCTZ in a range of clinical cohorts, grouped according to study design, duration of treatment, and patient selection.

\section{Clinical efficacy}

Evidence for the efficacy of olmesartan plus HCTZ, and the benefit of combination treatment over monotherapy with either agent, comes from 5 clinical trials. The design and features of these trials is shown in Table 1. Four of the

Table I Summary of studies examining the efficacy and safety of olmesartan medoxomil plus HCTZ

\begin{tabular}{|c|c|c|c|c|}
\hline Study reference & Design & Entry criteria & $\begin{array}{l}\text { Primary efficacy } \\
\text { endpoint }\end{array}$ & $\begin{array}{l}\text { Treatment arms/drug } \\
\text { dosages }\end{array}$ \\
\hline $\begin{array}{l}\text { Pooled factorial design } \\
\text { studies (Chrysant et al 2004; } \\
\text { Daiichi-Sankyo, Integrated } \\
\text { Summary of Efficacy, } \\
\text { data on file) }\end{array}$ & $\begin{array}{l}\text { Randomized, db, pc, pg, } \\
\text { mc, factorial design }\end{array}$ & $\begin{array}{l}\text { Mean seDBP } \\
100-115 \mathrm{mmHg} \text { at } \\
\text { weeks } 3 \text { and } 4 \text { of } \\
\text { placebo run-in }\end{array}$ & $\begin{array}{l}\text { Change from baseline in } \\
\text { mean trough seDBP at } \\
\text { week } 8 \text { or } 12\end{array}$ & $\begin{array}{l}\text { Placebo OLM (I0, } 20 \\
\text { or } 40 \mathrm{mg} / \text { day) HCTZ } \\
\text { (I } 2.5 \text { or } 25 \mathrm{mg} / \text { day) } \\
\text { OLM plus HCTZ } \\
\text { (all combinations) }\end{array}$ \\
\hline $\begin{array}{l}\text { HCTZ add-on cohort } \\
\text { (Sellin et al 2005) }\end{array}$ & $\begin{array}{l}\text { Partially randomized, } \\
\mathrm{db}, \mathrm{pc}, \mathrm{pg}, \mathrm{mc}\end{array}$ & $\begin{array}{l}\text { Mean seDBP } \\
\text { I00-II } 5 \mathrm{mmHg} \text { and } \\
\text { mean } 24 \text {-hour DBP } \\
\text { (by ABPM) } \geq 84 \mathrm{mmHg} \text {; } \\
\geq 30 \% \text { daytime DBP } \\
>90 \mathrm{mmHg} \text {; seDBP } \\
\geq 90 \mathrm{mmHg} \text { after } \\
\text { olmesartan run-in }\end{array}$ & $\begin{array}{l}\text { Change from baseline to } \\
\text { end of study (week I2) } \\
\text { in mean daytime DBP } \\
\text { (by ABPM) }\end{array}$ & $\begin{array}{l}\text { OLM ( } 20 \mathrm{mg} / \text { day }) \text { OLM } \\
\text { plus HCTZ ( } 20 \mathrm{mg} / \text { day } \\
\text { plus } 12.5 \text { or } 25 \mathrm{mg} / \text { day }\end{array}$ \\
\hline $\begin{array}{l}\text { Severe hypertensive cohort } \\
\text { (Ball et al 200I) }\end{array}$ & $\begin{array}{l}\text { Randomized, db, pg, mc, } \\
\text { double-dummy, dose- } \\
\text { titration, comparison } \\
\text { study }\end{array}$ & $\begin{array}{l}\text { Moderate-severe } \\
\text { essential I (seDBP } \\
100-120 \mathrm{mmHg} \text { ) at } \\
\text { end of HCTZ run-in. }\end{array}$ & $\begin{array}{l}\text { Change from baseline in } \\
\text { mean trough seDBP at } \\
\text { week } 12\end{array}$ & $\begin{array}{l}\text { OLM plus HCTZ ( } 10 \text { or } \\
20 \mathrm{mg} / \text { day plus } 25 \mathrm{mg} / \text { day) } \\
\text { Atenolol plus HCTZ ( } 50 \\
\text { or } 100 \mathrm{mg} \text { plus } 25 \mathrm{mg} / \text { day) }\end{array}$ \\
\hline $\begin{array}{l}\text { Treat-to-target cohort } \\
\text { (Neutel et al 2004, 2006) }\end{array}$ & $\begin{array}{l}\text { Open-label, } \\
\text { non-comparative, mc, } \\
\text { treat-to-target, with } \\
\text { 6-step treatment } \\
\text { algorithm }\end{array}$ & $\begin{array}{l}\text { Mean seDBP } \\
90-109 \mathrm{mmHg}\end{array}$ & $\begin{array}{l}\text { Change from study } \\
\text { baseline/treatment baseline } \\
\text { to the end of each 4-week } \\
\text { period using the LOCF } \\
\text { in seDBP and seSBP and } \\
\text { number of responders } \\
\text { (SBP } \leq 130 \mathrm{mmHg} \text {, DBP } \\
\leq 85 \mathrm{mmHg} \text { ). }\end{array}$ & $\begin{array}{l}\text { OLM ( } 20 \text { or } 40 \mathrm{mg} / \text { day) } \\
\text { OLM plus HCTZ } \\
(40 \mathrm{mg} / \text { day plus } 12.5 \text { or } \\
25 \mathrm{mg} / \text { day) OLM plus } \\
\text { HCTZ plus amlodipine } \\
\text { ( } 40 \mathrm{mg} / \text { day plus } 25 \mathrm{mg} / \text { day } \\
\text { plus } 5 \text { or } 10 \mathrm{mg} / \text { day) }\end{array}$ \\
\hline
\end{tabular}

Abbreviations: ABPM, ambulatory blood pressure monitoring; db, double-blind; HCTZ, hydrochlorothiazide; LOCF, last observation carried forward; mc, multicenter; OLM, olmesartan medoxomil; pc, placebo-controlled; pg, parallel-group; seDBP, seated diastolic blood pressure; seSBP, seated systolic blood pressure. 
studies were randomized, double-blind, multicenter studies that examined the efficacy of olmesartan alone or in combination with HCTZ using factorial dose-ranging design (2 studies); parallel group, HCTZ add-on design (1 study); or dose-titration, olmesartan add-on design (1 study). The fifth study was an open-label, dose-titration treat-to-target study in which patients received olmesartan in combination with HCTZ and/or amlodipine.

In all studies trough seated and standing blood pressure measurements were recorded with a standard mercury sphygmomanometer. Where ambulatory blood pressure monitoring (ABPM) was used, ABPM was recorded with a Spacelabs blood pressure monitor (Spacelabs GmbH, model 90207, Kaarst, Germany).

The primary efficacy end-point in the factorial studies and in the severe hypertension study was the change in trough seated DBP (seDBP) from baseline to the end of treatment (week 8, week 12, or the last post-baseline observation). Both DBP and SBP were measured at weeks 4, 8, and 12 of each study. The primary efficacy end-point in the HCTZ add-on cohort was the change in 24-hour mean ABPM between baseline (week 4 of treatment with HCTZ) and the end of treatment (week 12).

Each study reported the proportion of responders, defined in the factorial studies and the severe hypertension study as a mean seDBP $<90 \mathrm{mmHg}$ or a decrease of $\geq 10 \mathrm{mmHg}$ in seDBP at the end of treatment. In the HCTZ add-on study, responders were defined as having a mean daytime DBP of $\leq 85 \mathrm{mmHg}$ as measured by 24-hour ABPM.

In all cases, the last observation carried forward (LOCF) method was used to impute missing values and all statistical tests were two sided with a $\mathrm{p} \leq 0.05$ defined as statistically significant. In the factorial studies, which included 12 treatment groups, the significance level in the ANCOVA was defined as $0.05 \div 12$ (ie, p $\leq 0.004$ ). ANCOVA was used to compare the change from baseline blood pressure (seated DBP or 24-hour ABPM) in the different dosage groups in the various studies. In the severe hypertension study the combination of olmesartan/HCTZ was declared to be non-inferior to the combination of atenolol/HCTZ if the upper limit of a 2-sided 95\% confidence interval (CI) for the difference in least-squares means was $\leq 3.5 \mathrm{mmHg}$.

\section{Placebo-controlled factorial design studies}

The two factorial studies (Chrysant et al 2004; DaiichiSankyo, data on file) were of a sufficiently similar design to allow pooling and integration of data. This was conducted in an Integrated Summary of Efficacy, as shown in Table 1 (Daiichi-Sankyo, Integrated Summary of Efficacy, data on file). The studies were factorial dose-ranging studies designed to identify the optimum combination doses and to show that the combination for olmesartan and HCTZ is superior to each component alone. Response surface techniques using quadratic modeling were also used to model the optimal response within the range of experimental doses. Treatment was with olmesartan $0,10,20$, and $40 \mathrm{mg}$ and HCTZ 0, 12.5, and $25 \mathrm{mg}$ in all possible combinations.

The total ITT population in these pooled studies comprised 1986 patients. Of these, 979 received combination therapy; 498 olmesartan/placebo; 344 HCTZ/placebo; and 165 placebo only. The numbers of patients and their baseline characteristics were generally similar among the 12 treatment groups and an overview is shown in Table 2. Most patients in all treatment groups were Caucasian the mean age ranged from 53.4 to 55.3 years, and most patients in all treatment groups were $<65$ years of age.

A dose-dependent decrease from baseline in seDBP was seen with respect to both the olmesartan and HCTZ components (Figure 1a). Combination treatment with the higher doses of each monotherapy component produced substantial decreases from baseline in seDBP, with reductions of 19.6 and $20.1 \mathrm{mmHg}$ seen when olmesartan $20 \mathrm{mg}$ and $40 \mathrm{mg}$, respectively were added to HCTZ $25 \mathrm{mg}$. All combinations of olmesartan/HCTZ were significantly more effective compared with the respective dose of HCTZ monotherapy (Figure 1c) and all combinations of olmesartan/HCTZ $25 \mathrm{mg}$ were significantly more effective than the respective dose of olmesartan monotherapy (Figure 1c).

Decreases from baseline in seSBP at the primary endpoint paralleled those of seDBP, although reductions in mean seSBP were generally greater than the reductions in mean seDBP. The reductions were mainly dose-related for both olmesartan and HCTZ components (Figure 1b). Combination treatment with the higher doses of each component produced substantial decreases from baseline in seSBP, with reductions of at least $26 \mathrm{mmHg}$ seen when olmesartan $20 \mathrm{mg}$ and $40 \mathrm{mg}$, respectively were added to HCTZ $25 \mathrm{mg}$.

For both seDBP and seSBP, the effects of olmesartan and HCTZ were additive, which was confirmed using response surface modeling. When the analysis was restricted to the range of doses tested, the optimal dose of olmesartan/HCTZ for SBP reductions was estimated to be $27.1 \mathrm{mg} / 24.2 \mathrm{mg}$ (estimated to produce a mean decrease of $27.6 \mathrm{mmHg}$ ) and for DBP reduction was estimated to be $27.6 \mathrm{mg} / 24.1 \mathrm{mg}$ (estimated to produce a mean decrease of $20.6 \mathrm{mmHg}$ ). In practical 
Table 2 Comparison of demographic and baseline characteristics across studies assessing olmesartan and HCTZ

\begin{tabular}{|c|c|c|c|c|c|c|c|}
\hline \multirow[t]{2}{*}{ Study } & \multirow[t]{2}{*}{ No. patients } & \multirow{2}{*}{$\begin{array}{l}\text { Mean age } \\
\text { (years) }\end{array}$} & \multirow{2}{*}{$\begin{array}{l}\text { Sex } \\
\text { (\% male) }\end{array}$} & \multirow{2}{*}{$\begin{array}{l}\text { Ethnicity } \\
\text { (\% caucasian) }\end{array}$} & \multirow{2}{*}{$\begin{array}{l}\text { Hypertension } \\
\text { history (years) }\end{array}$} & \multicolumn{2}{|c|}{ Mean baseline seated BP } \\
\hline & & & & & & SBP & DBP \\
\hline $\begin{array}{l}\text { Pooled factorial design } \\
\text { studies (Chrysant et al } \\
\text { 2004; Daiichi-Sankyo, } \\
\text { Integrated Summary of } \\
\text { Efficacy, data on file) }\end{array}$ & 1986 & $53.4-55.3$ & $52.1 \%$ & $93.5 \%$ & $6.8-7.6$ & $157.2-160.7^{\mathrm{a}}$ & $103.6-104.3^{\mathrm{a}}$ \\
\hline $\begin{array}{l}\text { HCTZ add-on cohort } \\
\text { (Sellin et al 2005) }\end{array}$ & 535 & $52-54$ & $55.0 \%$ & $100 \%$ & $6.9-7.2$ & $147.4-150.4^{\mathrm{a}}$ & $95.3-95.8^{\mathrm{a}}$ \\
\hline $\begin{array}{l}\text { Severe hypertensive } \\
\text { cohort (Ball et al 200I) }\end{array}$ & 328 & $55.4-55.6$ & $47.9 \%$ & $100 \%$ & $6.2-6.8$ & $160.9-161.7^{\mathrm{a}}$ & $104.9-105.3^{*}$ \\
\hline $\begin{array}{l}\text { Treat-to-target cohort } \\
\text { (Neutel et al 2004; Neutel } \\
\text { et al 2006) }\end{array}$ & 198 & 52.8 & $65.2 \%$ & $73.7 \%$ & 8.3 & 161.2 & 96.6 \\
\hline
\end{tabular}

Abbreviations: DBP, diastolic blood pressure; HCTZ, hydrochlorothiazide; SBP, systolic blood pressure.

*mean for each treatment group (lowest and highest mean values).

terms, the optimal dose corresponds to the olmesartan/HCTZ $20 \mathrm{mg} / 25 \mathrm{mg}$ and $40 \mathrm{mg} / 25 \mathrm{mg}$ combinations.

The proportion of patients with a treatment response was higher for combination therapy than with either component alone (Table 3). Response rates were consistently higher in patients receiving olmesartan/HCTZ combination therapy than in those receiving the same respective doses of olmesartan or HCTZ with placebo. Among patients treated with olmesartan/HCTZ $20 \mathrm{mg} / 25 \mathrm{mg}$ or $40 \mathrm{mg} / 25 \mathrm{mg}$, more than $90 \%$ of patients were responders.

\section{HCTZ add-on study}

Conventional blood pressure measurements may be affected by so-called "white-coat hypertension", (Pickering et al 1988), in which a patient's anxiety may cause increases in blood pressure during monitoring in the clinic. Ambulatory blood pressure monitoring (ABPM) may offer a more accurate picture of a patient's blood pressure over the course of the day, and may therefore further demonstrate the efficacy of an antihypertensive agent over a 24-hour period (O'Brien et al 2003).

The effect of adding either $12.5 \mathrm{mg}$ or $25 \mathrm{mg}$ HCTZ to olmesartan $20 \mathrm{mg}$ on ABPM in patients whose DBP (measured by standard mercury sphygmomanometer) continued to be $\geq 90 \mathrm{mmHg}$ after 4 weeks of treatment with olmesartan $20 \mathrm{mg}$ monotherapy was assessed in a partially randomized, placebo-controlled trial (Sellin et al 2005). The ITT population comprised 535 individuals, with a total of 174,184 and 177 patients randomized to the olmesartan $20 \mathrm{mg} /$ placebo, olmesartan $20 \mathrm{mg} / \mathrm{HCTZ} 12.5 \mathrm{mg}$ and olmesartan $20 \mathrm{mg} / \mathrm{HCTZ} 25 \mathrm{mg}$ groups, respectively.
Additional analysis of data from this study in the Integrated Summary of Efficacy described above has determined that at baseline the mean daytime DBP as measured by 24-hour ABPM ranged from $88.3 \mathrm{mmHg}$ to $89.5 \mathrm{mmHg}$ across the three treatment groups (Daiichi-Sankyo, Integrated Summary of Efficacy, data on file). After 12 weeks of treatment the mean change in daytime DBP (the primary outcome) was significantly greater in patients treated with either olmesartan/HCTZ $20 \mathrm{mg} / 12.5 \mathrm{mg}(-2.67 \mathrm{mmHg}$; $\mathrm{p}=0.01)$ or $20 \mathrm{mg} / 25 \mathrm{mg}(-4.56 \mathrm{mmHg}$; $\mathrm{p}<0.0001)$ than with olmesartan $20 \mathrm{mg} /$ placebo (Table 4). Consistent with the primary outcome, the combination of olmesartan $20 \mathrm{mg} / \mathrm{HCTZ} 25 \mathrm{mg}$ produced statistically significant reductions in night-time DBP $(\mathrm{p}=0.0011)$, and in both daytime and night-time SBP and 24-hour DBP and SBP (all p < 0.0001) compared with olmesartan/placebo $20 \mathrm{mg}$.

Significant differences between the combination therapy groups and monotherapy was also demonstrated using conventional blood pressure measurement. After 12 weeks of treatment, reductions in mean trough seated DBP $(p=0.001)$ and SBP $(p=0.0002)$ were significantly greater with olmesartan $20 \mathrm{mg} / \mathrm{HCTZ} 25 \mathrm{mg}$ than with olmesartan/placebo.

The proportion of responders was greatest in patients treated with olmesartan $20 \mathrm{mg} / \mathrm{HCTZ} 25 \mathrm{mg}(70.7 \%)$ or olmesartan $20 \mathrm{mg} / \mathrm{HCTZ} 12.5 \mathrm{mg}$ (58.6\%) than with olmesartan/placebo (49.4\%).

Once again, olmesartan and HCTZ were demonstrated to have additive effects. The use of ABPM confirmed that olmesartan/HCTZ provides effective control throughout the 24-hour dosage interval, including during the early hours of the morning when the risk of cardiovascular events is highest. 

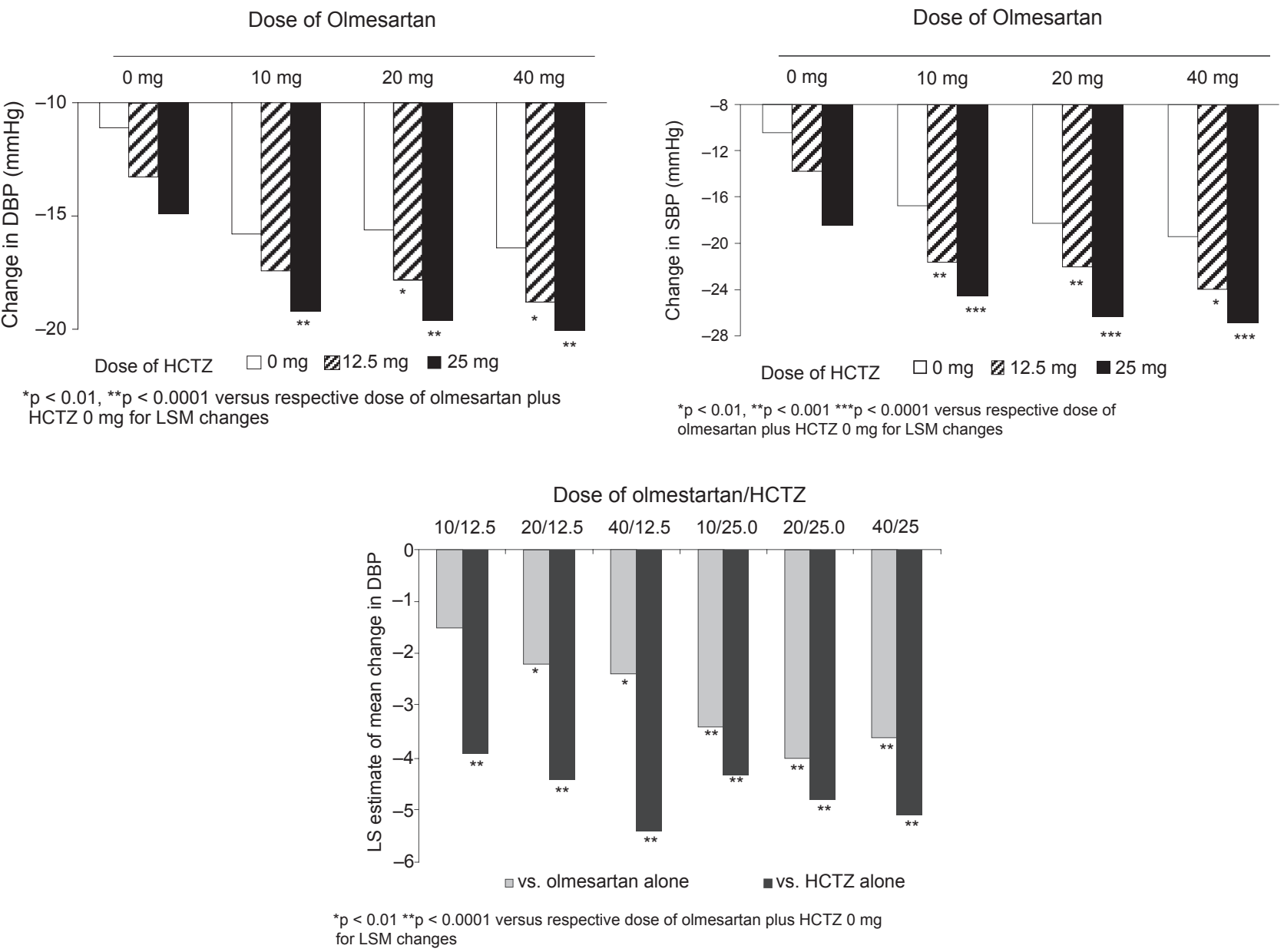

Figure I Change from baseline to end-point in (a) least squares mean (LSM) trough seated diastolic blood pressure (DBP) (b) LSM trough seated systolic blood pressure (SBP) and (c) treatment differences for change from baseline in DBP for dose comparisons: integrated analysis of two factorial studies.

Abbreviation: HCTZ, hydrochlorothiazide.

\section{Severe hypertension cohort}

Moderate to severe hypertension (SBP $\geq 160$ and/or DBP $\geq 100$ ) (Mancia et al 2007; Whitworth 2003) not only puts patients at greater risk for cardiovascular events, but is also more difficult to treat, with almost all patients requiring 2 or more antihypertensive agents. In 328 patients with moderate to severe essential hypertension, the efficacy of a combination of olmesartan and HCTZ was compared

Table 3 Percentage of patients with a treatment response in the combined factorial studies

\begin{tabular}{lllll}
\hline \multirow{2}{*}{ HCTZ $(\mathbf{m g})$} & $\mathbf{0}$ & $\mathbf{1 0}$ & $\mathbf{2 0}$ & $\mathbf{4 0}$ \\
\cline { 2 - 5 } $\mathbf{0}$ & $60.4 \%$ & $79.5 \%$ & $78.4 \%$ & $81.1 \%$ \\
$\mathbf{1 2 . 5}$ & $69.8 \%$ & $89.7 \%$ & $88.1 \%$ & $92.7 \%$ \\
$\mathbf{2 5}$ & $76.9 \%$ & $95.6 \%$ & $94.1 \%$ & $92.7 \%$ \\
\hline
\end{tabular}

Abbreviations: HCTZ, hydrochloroziazide; OLM, olmesartan medoxomil. with atenolol in a non-inferiority, dose titration study (Ball et al 2001). A 4-week single-blind placebo run-in phase was followed by single-blind treatment with HCTZ $25 \mathrm{mg}$ for 4 weeks. Patients whose DBP was $100-120 \mathrm{mmHg}$ after 4 weeks of HCTZ monotherapy were randomized to 12 weeks' treatment with olmesartan $10 \mathrm{mg} / \mathrm{HCTZ} 25 \mathrm{mg}$ $(\mathrm{n}=164)$ or atenolol $50 \mathrm{mg} / \mathrm{HCTZ} 25 \mathrm{mg}(\mathrm{n}=164)$. If mean seated DBP was $\geq 90 \mathrm{~mm} \mathrm{Hg}$ and/or the decrease in mean seated DBP from baseline was $<10 \mathrm{~mm} \mathrm{Hg}$ after 4 weeks' combination therapy, the dose of olmesartan or atenolol was doubled (ie, patients received olmesartan 20/HCTZ $25 \mathrm{mg}$ or atenolol $100 \mathrm{mg} / \mathrm{HCTZ} 25 \mathrm{mg}$ for the final 8 weeks of the treatment phase).

At baseline mean trough seated SBP/DBP was $160.9 / 104.9 \mathrm{~mm} \mathrm{Hg}$ and $161.7 / 105.3 \mathrm{mmHg}$ in patients randomized to olmesartan/HCTZ and atenolol/HCTZ, respectively (Daiichi-Sankyo, Integrated Summary of Efficacy, data on file). 
Table 4 Comparison of 24-hour ABPM values: change from baseline to week 12 - HCTZ add-on study

\begin{tabular}{llll}
\hline & Olmesartan $\mathbf{2 0} \mathbf{~ m g}$ & & \\
\cline { 2 - 4 } & Placebo & HCTZ I 2.5 $\mathbf{~ m g}$ & HCTZ 25 mg \\
\hline Daytime DBP LSM (95\% Cl) & $-2.22(-3.7 I,-0.73)$ & $-4.89(-6.34,-3.45)$ & $-6.78(-8.26,-5.30)$ \\
Night-time DBP LSM (95\% Cl) & $-2.79(-4.23,-1.35)$ & $-4.28(-5.69,-2.87)$ & $-6.08(-7.52,-4.65)$ \\
24-hour DBP LS mean (95\% Cl) & $-2.62(-3.94,-1.29)$ & $-4.75(-6.04,-3.46)$ & $-6.58(-7.90,-5.27)$ \\
Daytime SBP LSM (95\% Cl) & $-2.96(-5.21,0.72)$ & $-8.00(-10.17,-5.83)$ & $-11.70(-13.94,(-9.47)$ \\
Night-time SBP LSM (95\% Cl) & $-3.49(-5.66,-1.32)$ & $-7.22(-9.33,-5.11)$ & $-10.89(-13.05,-8.74)$ \\
24-hour SBP LSM (95\% Cl) & $-3.32,(-5.40,-1.24)$ & $-7.74(-9.76,-5.73)$ & $-11.37,(-13.44,-9.30)$ \\
\hline
\end{tabular}

Abbreviations: ABPM, ambulatory blood pressure monitoring; $\mathrm{Cl}$, confidence intervals; DBP, diastolic blood pressure; HCTZ, hydrochlorothiazide; LSM, least squares mean; SBP, systolic blood pressure.

After 12 weeks of treatment, the proportion of responders was $88.7 \%$ and $86.3 \%$, respectively among those treated with olmesartan/HCTZ and atenolol/HCTZ. The least squares mean reduction in trough seated SBP/DBP was $-21.1 /-17.6 \mathrm{mmHg}$ with olmesartan/ HCTZ and $-20.3 /-17.5 \mathrm{mmHg}$ with atenolol/HCTZ. The upper limit of the $95 \%$ CI for the difference in least squares means of DBP in the two treatment groups was $1.18 \mathrm{mmHg}$. This was below the $3.5 \mathrm{mmHg}$ defined as the non-inferiority limit, and so the combination of olmesartan (titrated up to the optimal dose of $20 \mathrm{mg}$ ) and HCTZ was shown to be at least as effective as atenolol (titrated up to the maximal dose of $100 \mathrm{mg}$ ) plus HCTZ in terms of lowering DBP (Daiichi-Sankyo, Integrated Summary of Efficacy, data on file).

\section{Treat-to-target study}

The majority of trials of antihypertensive agents concentrate on the mean reductions in blood pressure. However, many patients who respond to therapy (ie, have a reduction from baseline in DBP) may not achieve the target BP of $<140 / 90 \mathrm{mmHg}$ (or $<130 / 85$ for high-risk patients) (Chobanian et al 2003; Mancia et al 2007). The efficacy of olmesartan as part of a forced titration algorithm that involved 6 sequential treatment steps, each of 4 weeks' duration, to achieve a target BP of $\leq 130 / \leq 85 \mathrm{mmHg}$ has been assessed (Neutel et al 2004; Neutel et al 2006). As part of this algorithm, patients not only received olmesartan in combination with $\mathrm{HCTZ}$, but also as part of a triple combination with HCTZ and amlodipine.

The algorithm was as follows: olmesartan $20 \mathrm{mg}$, olmesartan $40 \mathrm{mg}$, olmesartan/HCTZ $40 \mathrm{mg} / 12.5 \mathrm{mg}$, olmesartan/HCTZ $40 \mathrm{mg} / 25 \mathrm{mg}$, olmesartan/HCTZ/ amlodipine $40 \mathrm{mg} / 12.5 \mathrm{mg} / 5 \mathrm{mg}$, and olmesartan/HCTZ/ amlodipine $40 \mathrm{mg} / 12.5 \mathrm{mg} / 10 \mathrm{mg}$. Treatment at each step was continued for 4 weeks and if the patient had not reached the goal BP, they advanced to the next step.
In a further analysis of the data derived from this study, mean changes from treatment baseline were calculated for DBP and SBP using observations before each step in the algorithm, and are demonstrated in Figure 2a and b (Daiichi-Sankyo, Integrated Summary of Efficacy, data on file). Further analysis examining the proportion of patients achieving the target blood pressure of $\leq 140 / \leq 90 \mathrm{mmHg}$ showed that at the end of the second step, when the maximal dose of olmesartan was being used, $57.5 \%$ of the 198 patients had reached target. At the end of the 4th treatment step, when the maximum doses of olmesartan and HCTZ were being used, the proportion of patients who had reached the $\leq 140 / \leq 90 \mathrm{mmHg}$ target was $82.1 \%$. When the analysis used the more stringent target of $\leq 130 / \leq 85 \mathrm{mmHg}$, the proportion of patients who had reached target at the end of the second and fourth steps was 33.0 and 65.4\%, respectively (Figure 2c) (Daiichi-Sankyo, Integrated Summary of Efficacy, data on file). The addition of amlodipine produced further reductions in BP so that by the end of the sixth treatment step (study end), when the maximum dose of all three agents was being used, the proportion of patients achieving the $\leq 140 / \leq 90$ and $\leq 130 / \leq 85 \mathrm{mmHg}$ goals was 92.7 and $83.8 \%$, respectively.

Given the estimate that only around one-third of patients have their blood pressure controlled to below $140 / 90 \mathrm{mmHg}$ (Chobanian et al 2003), the use of a stepped treatment approach such as this where over $90 \%$ of all patients, and more than $95 \%$ of patients with stage 1 hypertension (DaiichiSankyo, Integrated Summary of Efficacy, data on file) may reach this level shows great potential.

\section{Long-term studies}

Since patients with hypertension may require ongoing therapy, the ability of olmesartan in combination with HCTZ to provide effective blood pressure reduction over the long term has also been evaluated. A total of 1190 of the 1986 randomized patients who were responders in one of the placebo-controlled 

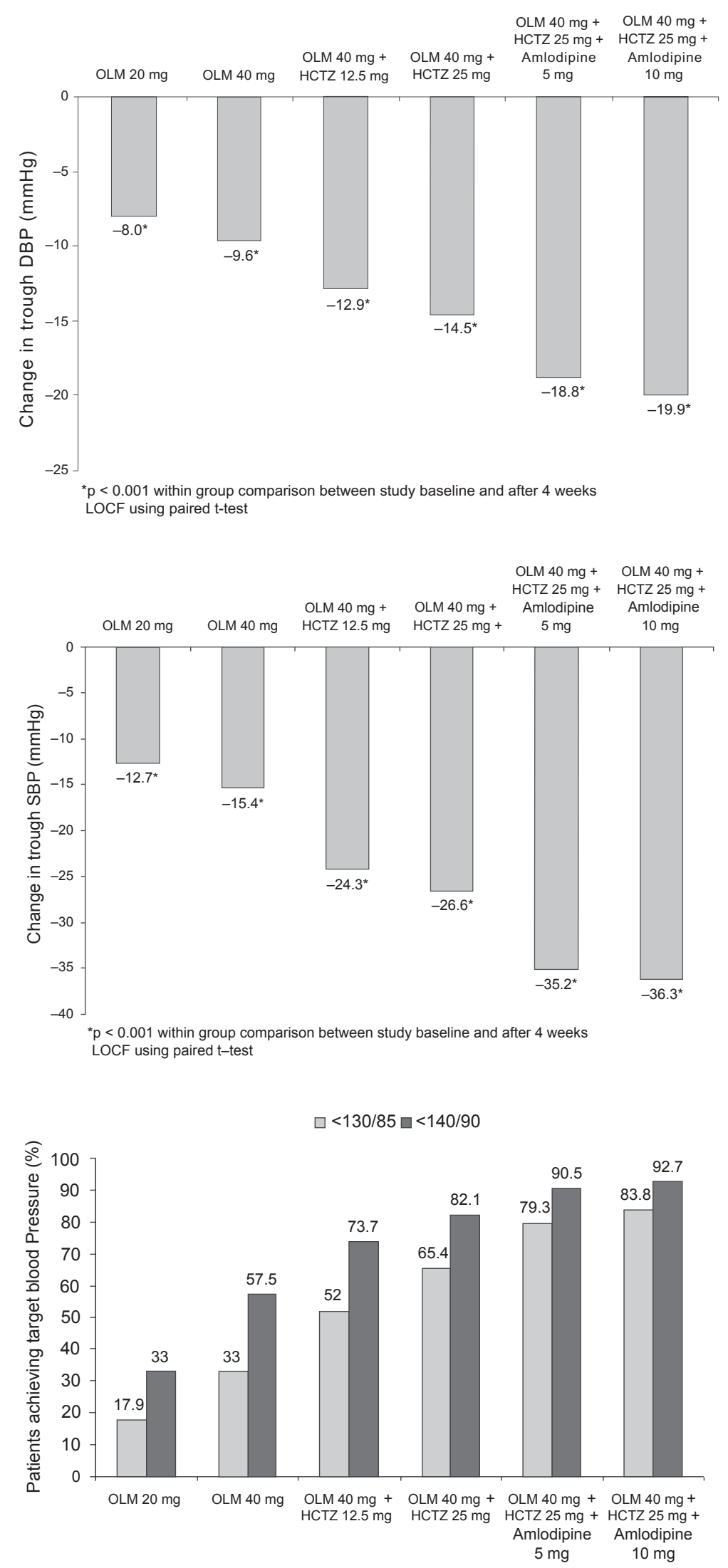

Figure 2 Mean change in (a) seated diastolic blood pressure (DBP) ( $\mathrm{mmHg}$ ) (b) systolic blood pressure (SBP) (mmHg) from study baseline at week 4 (LOCF) and (c) patients achieving target blood pressure by dose group in the treat-to-target cohort. Abbreviations: HCTZ, hydrochlorothiazide; OLM, olmesartan medoxomil. 
factorial studies (Daiichi-Sankyo, Integrated Summary of Efficacy, data on file) entered a 40-week long-term extension study, and of these, 74 patients received placebo, 288 patients received olmesartan alone, 178 patients received HCTZ alone, and 650 patients received combination therapy.

Notable decreases from baseline to last visit were seen for all treatment responders, and, as seen in the 12-week double-blind phase of the study, these greater decreases were seen in the combination therapy groups than in the placebo or monotherapy groups (Figure 3). The between-group differences were greater for SBP than DBP, and this could be expected due to the fact that this cohort of patients was permitted to continue in the extension phase only if they were already treatment responders.

Patients who received olmesartan/HCTZ $20 \mathrm{mg} / 25 \mathrm{mg}$ or $40 \mathrm{mg} / 25 \mathrm{mg}$ achieved mean trough seated SBP/DBP of $<140 / 90 \mathrm{mmHg}$ at the end of treatment.

The second placebo-controlled factorial study (Chrysant et al 2004) allowed patients to continue receiving open-label treatment for 4 months with
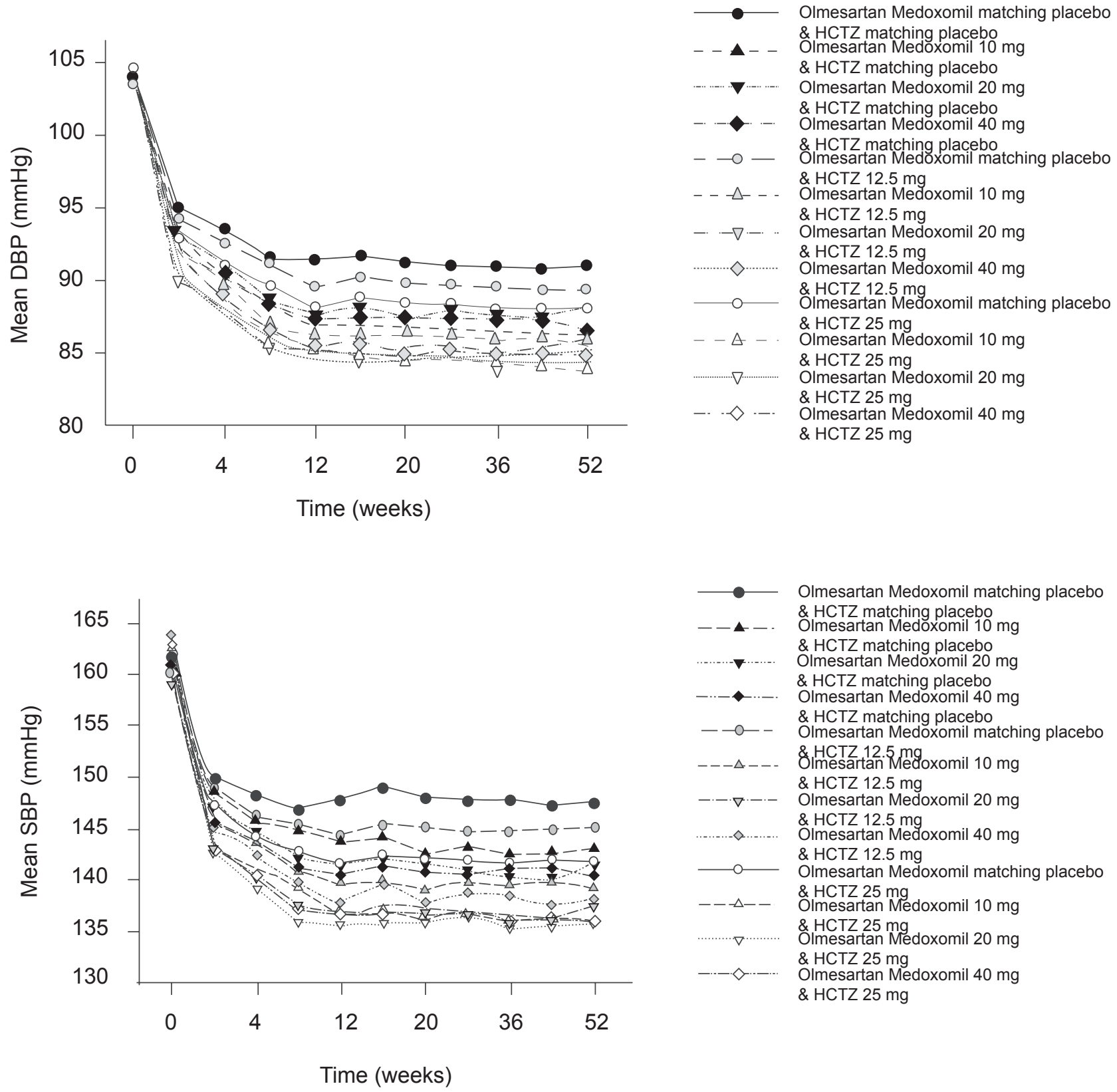

Figure 3 Changes in mean (a) seated diastolic blood pressure (DBP) and (b) systolic blood pressurse (SBP) over the 52-week treatment period by group in the long-term cohort. Abbreviation: HCTZ, hydrochlorothiazide. 
olmesartan/HCTZ $20 \mathrm{mg} / 12.5 \mathrm{mg}$, titrating HCTZ to $25 \mathrm{mg}$ in 53/340 patients whose blood pressure was poorly controlled on the lower dose (Daiichi-Sankyo, Integrated Summary of Efficacy, data on file). Blood pressure was reduced in patients receiving both treatment regimens, to a mean of $128.1 / 83.2$ in patients receiving the lower dose of HCTZ and to a mean of 138.6/91.9 in patients requiring $\mathrm{HCTZ} 25 \mathrm{mg}$.

The long-term extension results from these two studies demonstrate that the blood pressure lowering effects of combination therapy are maintained over time, and reiterate the additive effects of olmesartan and HCTZ.

\section{Safety}

An Integrated Summary of Safety was conducted in order to analyze the adverse events that occurred during the studies listed above (Daiichi-Sankyo, Integrated Summary of Safety, data on file). In the placebo-controlled factorial studies, dizziness was the most commonly reported adverse event in patients receiving olmesartan/HCTZ combination therapy, although no adverse event was significantly more frequent than another. Interestingly, dizziness became less common over time, as patients who continued into the long-term extension phase reported fewer incidences.

In the HCTZ add-on study, the incidence of adverse events was low, with $6.1 \%-6.6 \%$ of patients reporting at least one adverse event across the treatment groups. A total of 6 patients in this study withdrew from the study due to adverse events, all of whom were receiving olmesartan monotherapy. These findings suggest that the addition of HCTZ to olmesartan does not increase the incidence of adverse events.

In the severe hypertensive cohort, patients receiving olmesartan/HCTZ combination therapy experienced fewer adverse events than patients receiving the atenolol/HCTZ combination (34.8 versus $37.2 \%$ ). Events such as headache, dizziness and vertigo were more frequent in the olmesartan/ HCTZ group. Although 2 patients in the olmesartan/HCTZ group compared with 1 patient in the atenolol/HCTZ group experienced a treatment emergent severe adverse event, none of these events were considered to be related to study medication.

The pattern was again similar in the treat-to-target cohort, in which the overall incidence of treatment emergent adverse events was about $40 \%$. Most of these events were considered unrelated to the study medication, and were mild or moderate.

Across all the studies described here, $44 \%$ of patients on combination therapy, $49 \%$ of placebo patients, $41 \%$ of HCTZ patients and $47 \%$ of olmesartan patients reported treatmentemergent adverse events (Daiichi-Sankyo, Integrated Summary of Safety, data on file). Most adverse events were mild or moderate in nature, with only $6 \%$ of events reported as severe. Overall, $20 \%$ of adverse events were considered to be treatment related. The frequencies of discontinuations due to adverse events were similar across olmesartan monotherapy (2.7\%), HCTZ monotherapy (3.2\%), combination therapy $(2.3 \%)$ and placebo groups (3.0\%). Four patient deaths were recorded in one of the placebo-controlled factorial studies, but only one of these was considered possibly related to study medication. Overall, the proportion of adverse events considered to be treatment related, and the low proportion of severe adverse events reported indicate that olmesartan and HCTZ are well-tolerated therapies, alone and in combination.

\section{Discussion}

The clinical studies included in this review demonstrate that olmesartan combined with HCTZ provides a high degree of clinical efficacy combined with good tolerability. Doseranging data have demonstrated that the combination of olmesartan and HCTZ produces dose-dependent increases in BP-reducing efficacy (Daiichi-Sankyo, data on file). This review provides further evidence of this by combining data from two dose-ranging studies that used a similar factorial design and methodology. The add-on study was included since it demonstrates the effect of adding HCTZ to patients already receiving olmesartan and the treat-to-target study is important since it illustrates that a stepped approach to antihypertensive treatment based upon olmesartan and HCTZ can increase the numbers of patients who achieve BP targets. The study in patients with moderate-to-severe hypertension was included to illustrate the efficacy of the combination in these harder-to-treat patients.

With the large number of patients worldwide whose hypertension remains poorly controlled, there is a clear clinical need for effective and well-tolerated therapies that combine different antihypertensive agents. In fact more than two-thirds of patients with hypertension will require combination therapy with two or more antihypertensive agents from different drug classes to achieve target blood pressure (Cushman et al 2002; Chobanian et al 2003). Thiazide diuretics such as HCTZ continue to form the foundation of anti-hypertensive therapy and their mechanism of action is complementary to that of ARBs, enhancing the efficacy of both agents. This effect is demonstrated in the pooled data from the two factorial studies that demonstrate that the blood pressure lowering effects of olmesartan and HCTZ 
are additive, in that combination therapy with olmesartan and HCTZ is significantly better than monotherapy with either drug, except when low-dose combinations are used. In addition, the percentage of patients responding to therapy ( $>10 \mathrm{mmHg}$ decrease from baseline) is higher in patients receiving combination therapy than in those receiving monotherapy, and decreases from baseline in both DBP and SBP are dose related.

The findings of the studies described in this review are supported by other studies in which the efficacy of olmesartan in combination with HCTZ has been assessed (Barrios et al 2007; Kereiakes et al 2007). In the OLMEBEST study, patients with mild-to-moderate hypertension who had a DBP $<90 \mathrm{mmHg}$ after 8 weeks of open label treatment with olmesartan $20 \mathrm{mg}$ randomly received olmesartan $40 \mathrm{mg}$ or olmesartan $20 \mathrm{mg} / \mathrm{HCTZ} 12.5 \mathrm{mg}$ for a further 4 weeks. Each randomized treatment led to a further reduction in BP beyond that produced by the open label treatment. At the end of the randomized treatment phase, patients who had received olmesartan $20 \mathrm{mg} / \mathrm{HCTZ} 12.5 \mathrm{mg}$ showed larger a change in SBP and DBP (-10.8 and $-7.9 \mathrm{mmHg}$, respectively) than the olmesartan $40 \mathrm{mg}$ group $(-5.3$ and $-5.1 \mathrm{mmHg}$ ), although these differences were not significant (Barrios et al 2007). In addition, a forced titration regimen beginning with olmesartan monotherapy ( 20 followed by $40 \mathrm{mg}$ ) followed by the addition of HCTZ (12.5 followed by $25 \mathrm{mg}$ ) was compared with forced titration based upon benazepril monotherapy (10 followed by $20 \mathrm{mg}$ ) to which amlodipine ( 5 followed by $10 \mathrm{mg}$ ) was added (Kereiakes et al 2007). At study end, the olmesartan/HCTZ group showed a significantly larger change in SBP $(-32.5 \mathrm{mmHg}$; primary endpoint) than the the benazepril/amlodipine group $(-26.5 \mathrm{mmHg}, \mathrm{p}=0.024)$. Also, a significantly greater proportion of patients achieved the BP goals of $<140 / 90,130 / 85$, and $130 / 80 \mathrm{mmHg}$ (66.3, 44.9 , and $32.6 \%$, respectively) with olmesartan/HCTZ compared with the benazepril/amlodipine group (44.7, 21.2, and 14.1\%) (Kereiakes et al 2007).

When given as monotherapy, olmesartan produces greater reductions in blood pressure than a range of other agents in this class (Brunner and Laeis 2003). While this current review does not compare the combination of olmesartan and HCTZ with other $\mathrm{ARB} / \mathrm{HCTZ}$ combinations, previous studies have been conducted examining the efficacy of other ARBs in combination with HCTZ. Candesartan, telmisartan, losartan and valsartan have all been used in combination with HCTZ, and have demonstrated blood pressure lowering in the range of 4.5-9 $\mathrm{mmHg}$ for DBP and in the range of 6.8-12.6 $\mathrm{mmHg}$ for SBP, compared with monotherapy regimens (Campbell et al
2001; Lacourciere et al 2001; Waeber et al 2001; Lacourciere and Poirier 2003; Lacourciere et al 2003; Watanabe et al 2006). A published systematic review examining factorial design trials of ARBs combined with HCTZ demonstrated that after 8 weeks of therapy, olmesartan plus HCTZ achieved the greatest reductions in DBP and SBP when compared with irbesartan/HCTZ, telmisartan/HCTZ, and valsartan/HCTZ (Ram 2004). While such a review of the literature is limited due to inherent differences in the design of the factorial studies as well as the lack of statistical analysis of findings, it does demonstrate the efficacy of ARB/HCTZ combinations in general, and supports further research in the form of head-to-head trials. A recently published meta-analysis of the antihypertensive efficacy of ARBs in studies using 24-hour ABPM found differences in both the magnitude and duration of antihypertensive activity between ARBs (Fabia et al 2007). Although the analysis was not designed to determine which ARB had the greatest efficacy, the data presented showed that BP reductions were generally greater with olmesartan, including in the critical last four hours of the interdose period. This review also demonstrated that adding HCTZ to ARBs provided further additional reduction in BP.

The results presented here demonstrate that olmesartan is highly effective when added to ongoing HCTZ monotherapy or, conversely, when HCTZ is added to ongoing olmesartan monotherapy. Moderate to severe hypertension also responds well to olmesartan therapy, and efficacy continues to be maintained over the long term.

A further analysis of the treat-to-target study has shown that in patients with stage 1 hypertension (baseline SBP 140-159 mmHg or DBP 90-99 $\mathrm{mmHg}$ ) at the end of the 4th treatment step, when the high doses of olmesartan and HCTZ were being used, mean trough seated DBP was $\leq 90 \mathrm{mmHg}$ in $97.5 \%$ of patients, and $\leq 85 \mathrm{mmHg}$ in $94.9 \%$ of patients, and $93.7 \%$ of patients had achieved a combined BP goal of $\leq 140 / 90 \mathrm{mmHg}$ (Neutel et al 2006). In patients with the more severe stage 2 hypertension (baseline $\mathrm{SBP} \geq 160 \mathrm{mmHg}$ or DBP $\geq 100 \mathrm{mmHg}$ ), the respective proportions of patients with DBP $\leq 90$ and $\leq 85 \mathrm{mmHg}$ were 95.0 and $81.0 \%$ and $75.0 \%$ of patients had achieved the combined BP goal of $\leq 140 / 90 \mathrm{mmHg}$ at the end of the 4 th treatment step. The addition of amlodipine to this stepped treatment protocol produced even greater percentages of goal rate achievement in each group of patients (Neutel et al 2006).

These goal rate results obtained with olmesartan plus HCTZ appear to be reproducible for other ARB combinations. The combination of losartan and HCTZ has also been shown to be significantly better than monotherapy in achieving goal 
rates, although the percentage of patients reaching goal was smaller overall (Salerno et al 2004).

The use of ABPM may offer additional benefits in measuring BP over a 24-hour period, and may be especially important in assessing patients at increased risk of cardiovascular events (Chobanian et al 2003). As well as olmesartan, other ARB/HCTZ combinations have been assessed using ABPM (Lacourciere and Poirier 2003; de la Sierra et al 2004; Neutel et al 2005; White et al 2006) and consistently show that combination therapy results in greater decreases from baseline and higher response rates throughout the entire 24-hour period than placebo or monotherapy.

While the efficacy of olmesartan and HCTZ has been proven to be additive, a previous meta-analysis of combination therapy has demonstrated that the prevalence of adverse events was significantly lower than would be expected with an additive effect (Law et al 2003). The studies analyzed in this review confirm that the combination of olmesartan/ HCTZ is well tolerated, and that the incidence of adverse events is similar in combination and monotherapy groups.

\section{Conclusion}

Olmesartan plus HCTZ produces additive reductions in blood pressure and, when given at the optimal dose $20 / 25 \mathrm{mg}$ or $40 / 25 \mathrm{mg}$, produces double-digit reductions in DBP and SBP. Thus olmesartan/HCTZ is a well-tolerated option for patients who fail to respond to monotherapy and as initial therapy in those who require large reductions in DBP or SBP to achieve goal blood pressure.

\section{Disclosures}

The author has no conflicts of interest to declare.

\section{References}

Ball KJ, Williams PA, Stumpe KO. 2001. Relative efficacy of an angiotensin II antagonist compared with other antihypertensive agents. Olmesartan medoxomil versus antihypertensives. J Hypertens Suppl, 19:S49-56.

Barrios V, Boccanelli A, Ewald S, et al. 2007. Efficacy and tolerability of olmesartan medoxomil in patients with mild to moderate essential hypertension: the OLMEBEST Study. Clin Drug Investig, 27:545-8.

Benz JR, Black HR, Graff A, et al. 1998. Valsartan and hydrochlorothiazide in patients with essential hypertension. A multiple dose, double-blind, placebo controlled trial comparing combination therapy with monotherapy. J Hum Hypertens, 12:861-6.

Brunner HR, Laeis P. 2003. Clinical efficacy of olmesartan medoxomil. J Hypertens Suppl, 21(Suppl 2):S43-6.

Campbell M, Sonkodi S, Soucek M, et al. 2001. A candesartan cilexetil/ hydrochlorothiazide combination tablet provides effective blood pressure control in hypertensive patients inadequately controlled on monotherapy. Clin Exp Hypertens, 23:345-55.

Chobanian AV, Bakris GL, Black HR, et al. 2003. The Seventh Report of the Joint National Committee on Prevention, Detection, Evaluation, and Treatment of High Blood Pressure: the JNC 7 report. JAMA, 289:2560-72.
Chrysant SG, Weber MA, Wang AC, et al. 2004. Evaluation of antihypertensive therapy with the combination of olmesartan medoxomil and hydrochlorothiazide. Am J Hypertens, 17:252-9.

Cushman WC, Ford CE, Cutler JA, et al. 2002. Success and predictors of blood pressure control in diverse North American settings: the antihypertensive and lipid-lowering treatment to prevent heart attack trial (ALLHAT). J Clin Hypertens (Greenwich), 4:393-404.

Dahlof B, Devereux RB, Kjeldsen SE, et al. 2002. Cardiovascular morbidity and mortality in the Losartan Intervention For Endpoint reduction in hypertension study (LIFE): a randomised trial against atenolol. Lancet, 359:995-1003.

Daiichi Sankyo, Data on file.

Daiichi Sankyo, Integrated Summary of Efficacy. Data on file.

Daiichi Sankyo, Integrated Summary of Safety. Data on file.

de la Sierra A, Gil-extremera B, Calvo C, et al. 2004. Comparison of the antihypertensive effects of the fixed dose combination enalapril $10 \mathrm{mg} /$ nitrendipine $20 \mathrm{mg}$ vs losartan $50 \mathrm{mg} /$ hydrochlorothiazide $12.5 \mathrm{mg}$, assessed by $24-\mathrm{h}$ ambulatory blood pressure monitoring, in essential hypertensive patients. J Hum Hypertens, 18:215-22.

Fabia MJ, Abdilla N, Oltra R, et al. 2007. Antihypertensive activity of angiotensin II AT1 receptor antagonists: a systematic review of studies with $24 \mathrm{~h}$ ambulatory blood pressure monitoring. J Hypertens, 25:1327-36

Hansson L, Zanchetti AM, Carruthers SG, et al. 1998. Effects of intensive blood-pressure lowering and low-dose aspirin in patients with hypertension: principal results of the Hypertension Optimal Treatment (HOT) randomised trial. HOT Study Group. Lancet, 351:1755-62.

Kereiakes DJ, Neutel JM, Punzi HA, et al. 2007. Efficacy and safety of olmesartan medoxomil and hydrochlorothiazide compared with benazepril and amlodipine besylate. Am J Cardiovasc Drugs, 7:361-72.

Kochar M, Guthrie R, Triscari J, et al. 1999. Matrix study of irbesartan with hydrochlorothiazide in mild-to-moderate hypertension. Am J Hypertens, 12:797-805.

Lacourciere Y, Gil-Extremera B, Mueller O, et al. 2003. Efficacy and tolerability of fixed-dose combinations of telmisartan plus HCTZ compared with losartan plus HCTZ in patients with essential hypertension. Int $J$ Clin Pract, 57:273-9.

Lacourciere Y, Poirier L. 2003. Antihypertensive effects of two fixed-dose combinations of losartan and hydrochlorothiazide versus hydrochlorothiazide monotherapy in subjects with ambulatory systolic hypertension. Am J Hypertens, 16:1036-42.

Lacourciere Y, Tytus R, O’Keefe D, et al. 2001. Efficacy and tolerability of a fixed-dose combination of telmisartan plus hydrochlorothiazide in patients uncontrolled with telmisartan monotherapy. J Hum Hypertens, 15:763-70.

Law MR, Wald NJ, Morris JK, et al. 2003. Value of low dose combination treatment with blood pressure lowering drugs: analysis of 354 randomised trials. $B M J, 326: 1427$.

Lewington S, Clarke R, Qizilbash N, et al. 2002. Age-specific relevance of usual blood pressure to vascular mortality: a meta-analysis of individual data for one million adults in 61 prospective studies. Lancet, 360:1903-13.

Mancia G, De Backer G, Dominiczak A et al. 2007 Guidelines for the Management of Arterial Hypertension: The Task Force for the Management of Arterial Hypertension of the European Society of Hypertension (ESH) and of the European Society of Cardiology (ESC). J Hypertens, 25:1105-87.

Neutel JM, Littlejohn TW, Chrysant SG, et al. 2005. Telmisartan/ hydrochlorothiazide in comparison with losartan/hydrochlorothiazide in managing patients with mild-to-moderate hypertension. Hypertens Res, 28:555-63.

Neutel JM, Smith DH, Silfani TN, et al. 2006. Effects of a structured treatment algorithm on blood pressure goal rates in both stage 1 and stage 2 hypertension. J Hum Hypertens, 20:255-62.

Neutel JM, Smith DH, Weber MA, et al. 2004. Use of an olmesartan medoxomil-based treatment algorithm for hypertension control. J Clin Hypertens (Greenwich), 6:168-74. 
O’Brien E, Asmar R, Beilin L, et al. 2003. European Society of Hypertension recommendations for conventional, ambulatory and home blood pressure measurement. J Hypertens, 21:821-48.

Pickering TG, James GD, Boddie C, et al. 1988. How common is white coat hypertension? JAMA, 259:225-8.

Psaty BM, Lumley T, Furberg CD, et al. 2003. Health outcomes associated with various antihypertensive therapies used as first-line agents: a network meta-analysis. JAMA, 289:2534-44.

Psaty BM, Smith NL, Siscovick DS, et al. 1997. Health outcomes associated with antihypertensive therapies used as first-line agents. A systematic review and meta-analysis. JAMA, 277:739-45.

Puchler K, Laeis P, Stumpe KO. 2001. Blood pressure response, but not adverse event incidence, correlates with dose of angiotensin II antagonist. J Hypertens Suppl, 19:S41-8.

Ram CV. 2004. Antihypertensive efficacy of angiotensin receptor blockers in combination with hydrochlorothiazide: a review of the factorial-design studies. J Clin Hypertens (Greenwich), 6:569-77.

Salerno CM, Demopoulos L, Mukherjee R, et al. 2004. Combination angiotensin receptor blocker/hydrochlorothiazide as initial therapy in the treatment of patients with severe hypertension. J Clin Hypertens (Greenwich), 6:614-20
Sellin L, Stegbauer J, Laeis P, et al. 2005. Adding hydrochlorothiazide to olmesartan dose dependently improves 24-h blood pressure and response rates in mild-to-moderate hypertension. J Hypertens, 23:2083-92.

Stumpe KO, Ludwig M. 2002. Antihypertensive efficacy of olmesartan compared with other antihypertensive drugs. J Hum Hypertens, 16(Suppl 2):S24-48.

Waeber B, Aschwanden R, Sadecky L, et al. 2001. Combination of hydrochlorothiazide or benazepril with valsartan in hypertensive patients unresponsive to valsartan alone. $J$ Hypertens, 19:2097-104.

Watanabe LA, Wei M, Sun N, et al. 2006. Effect on blood pressure control of switching from valsartan monotherapy to losartan/hydrochlorothiazide in Asian patients with hypertension: results of a multicentre open-label trial. Curr Med Res Opin, 22:1955-64.

White WB, Giles T, Bakris GL, et al. 2006. Measuring the efficacy of antihypertensive therapy by ambulatory blood pressure monitoring in the primary care setting. Am Heart J, 151:176-84.

Whitworth JA. 2003. 2003 World Health Organization (WHO)/International Society of Hypertension (ISH) statement on management of hypertension. J Hypertens, 21:1983-92. 